\title{
The Implementation of Android-Based Application as a Media for Teaching English in Simple Present Tense
}

\author{
Dewi Yana ${ }^{1}$; Farahdila Fajar Darwati ${ }^{2}$ \\ English Education Department \\ University of Riau Kepulauan \\ alifdewi@yahoo.com² ; farahdila.farah2@gmail.com ${ }^{1}$
}

\begin{abstract}
This research was conducted to figure out whether the implementation of android-based application can improve students' understanding in simple present tense and to find out the responses of students toward the implementation of the media. This classroom action research is done at the eighth grade students of Fatmawati Learning and Education Center (FLEC) in academic year 2016/2017. It contained 15 students in the classroom. This study had two cycles done and used tests, field notes and interview as the instruments to gather the data. The finding of the research shows that there are significant improvements of students' achievements since the implementation of the media until the last cycle of the research. It was proved by the improvement resulted in two cycles. According to the results, there are significant improvements in each cycle. The result of pre-test showed that there were only two students or $13.33 \%$ passed the exam. The mean of pre-test was 55.67. From the result of first cycle, it can be concluded that there is $28.13 \%$ improvement of the result from pre-test. It is proven by the improvement of classroom success and mean. In the first cycle, classroom success is $53.33 \%$ and the mean increased to be 71.33. The last cycle is cycle two. It was successful by the result of students. There are 13 students were successful passing the exam and only two students failed. It gave result to the classroom success about $86.67 \%$ with the score mean 84 . The study also results responses from students toward the media usage in the classroom from students' interview and field notes. From students' interview, researcher concluded that the implementation of android-based application as media for teaching in the classroom could solve the problem and increase students' understanding in learning simple present tense. Based on the data of field notes, researcher found positive and desired response from the students during the observation. It was observed from verbal and non-verbal responses shown by the students.
\end{abstract}

Keywords : android-based application, simple present tense, students' response

\section{INTRODUCTION}

The use of media in teaching and learning is very important. Both teacher and student are helped by the existence of media in classroom. For teachers, media help them to deliver the material more and better. Media also helps teacher to get more attention from 
students while teaching. Meanwhile, for students, media help them to get more comprehension what material is delivered by teacher and more interest in learning.

The revolution of media is supported by development of technology. Some of the examples are internet and smartphone. There are several advantages smartphone has in education. Interaction tendency is enhanced by mobile applications. So it can make students more interactive and active in classroom. Smartphone makes learning is no more a passive activity but it's active with applications. Unlike school, mobile applications are available 24/7. By smartphone, it can be utilized to learn something new with the help from a learning

app. Based on the advantages, researcher assumed that the use of smartphone applications can solve researcher's problems in teaching English especially teaching simple present tense in eighth grade.

\section{Simple Present Tense}

The simple present tense is used to describe everyday activities and habits, to make general statement of fact, and to express opinions. According to Hornby in Dewifartina (2011:12) the usage of simple present tense divided into five kinds:

a. To describes an activity that is actually in progress at the moment of speaking.

b. To be used in commentaries.

c. To be used in exclamatory sentences beginning with here and there.

d. In the general statement of what was true in past, present and true in future time.

e. To be used for references to what was communicated in the past.

\section{Media in Teaching}

Gagne in Ruis (2009:2) defines that media are various components in learners' environment which support the learners learn. In Ruis (2009:2), Briggs also defines media are physical means which are used to send messages to the students and stimulate them to learn. Vernon in Ruis (2009) states that there are six kinds of media that are explained as below:

1. Drawing or teacher mode drawings

2. Still pictures

3. Audio recording

4. Motion picture and TV

5. Real object, simulation and models

6. Programmed and computer-assisted instruction

According to Sukartiwi in Ruis (2009), there are some advantages of using media in teaching-learning process. Those advantages are explained as below:

1) to increase the learners' motivation. 
2) to avoid the learners bored.

3) to make the learners easy to understand the instructional material.

4) to make the teaching learning process more systematic

\section{Android-Based Applications in Research}

In this research, researcher did not observed all of the android mobile application. Because of the heterogeneity of the contents in each application, researcher chose several applications that are suitable based on the learning material delivered in this research. Researcher decided to apply English Grammar in Use and 5555 English Grammar Tests. English Grammar in Use was applied for explaining the theory of simple present tense and 5555 English Grammar Tests was applied for students' post-test I and post-test II. Researcher used android emulator for operating android application on laptop named Nox App Player.

\section{Students' Response}

According to McKechnie as cited in Silaban (2014) response is an act or action of responding. Borich as cited in Silaban (2014) that there are two kinds of students' responses, the first is desired responses and the second is undesired responses. Those responses are seen from the point of view of the teacher. Responses typically are divided in verbal and nonverbal responses. There are also positive responses and negative responses based on their influence to the teaching and learning process.

\section{METHODOLOGY}

According to Kemmis quoted by D. Hopkins (2008) defined action research as a form of self-reflective enquiry undertaken by participants in social situations in order to improve the rationality and justice of their own social or educational practices, as well as their understanding of these practices and the situation in which these practices are carried out. This Classroom Action Research is conducted in two cycles. Each cycle contains planning, acting, observing and reflecting. This study was done in the first week of July in 2017. This research was done at the eighth grade of Fatmawati Learning and Education Center (FLEC) where researcher teaches her students. The Instruments used in this study were tests, field notes, and interview. The technique of collecting data was done by observation and interview.

The data gathered in this study were analyzed in qualitative and quantitative. Quantitative analysis was used to analyze quantitative data, i.e. the data on students' test 
score. In this research, the researcher used test in two cycles. Before the cycle is of pre-test and after the cycle is post-test. According to Ovalina (2010), there are several calculation used to analyze data in Classroom Action Research (CAR). The formulations are explained as below.

\section{a. Students' Score}

Students' score $(S)=\frac{\text { Obtained Score }(\mathrm{R})}{\text { Maximum Score }(\mathrm{N})} \times 100$

b. Mean

$$
\overline{\mathrm{X}}=\frac{\Sigma \mathrm{x}}{\mathrm{N}}
$$

$\mathrm{X}: \overline{\text { Mean }}$

$\mathrm{X}$ : Score

$\mathrm{N}$ : Number of score

$\Sigma$ : Sum or Add

c. Percentage of Classroom Success

$$
\mathrm{P}=\frac{\mathrm{F}}{\mathrm{N}} \times 100 \%
$$

$\mathrm{P}=$ The class percentage

$\mathrm{F}=$ Total Percentage score

$\mathrm{N}=$ Number of students

d. Percentage of Students' Improvement in Post-Test I

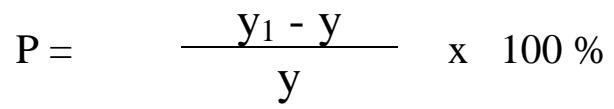

$\mathrm{P}=$ Percentage of student's improvement

$\mathrm{y}=$ Pre-test result

$\mathrm{y}_{1}=$ Post-test I

e. Percentage of Students' Improvement in Post-Test II

$$
\begin{aligned}
& \mathrm{P}=\frac{\mathrm{y}_{2}-\mathrm{y}}{\mathrm{y}} \times 100 \% \\
& \mathrm{P}=\text { Percentage of student's improvement } \\
& \mathrm{y}=\text { Pre-test result }
\end{aligned}
$$




$$
\mathrm{y}_{2}=\text { Post-test II }
$$

\section{RESULTS}

The first result is that the mean of students' achievement in pre-test, post-test I and post-test II increased consistently after the implementation of android-based application in teaching simple present tense in the classroom. The improvement can be seen from the increasing value. The mean of pre-test is 55.67 , the mean of post-test I is 71.33 and the mean of post-test II is 84 . The second result from the calculation is the percentage of classroom's success from pre-test to post-test II. In pre-test, the success of classroom is $13.33 \%$. In posttest I, the result is $53.33 \%$. In post-test II, the result is $86.67 \%$. In can be concluded that there are $40 \%$ improvement from pre-test to post-test I and $33.34 \%$ from post-test I to post-test II. the results of the test can be described as below.

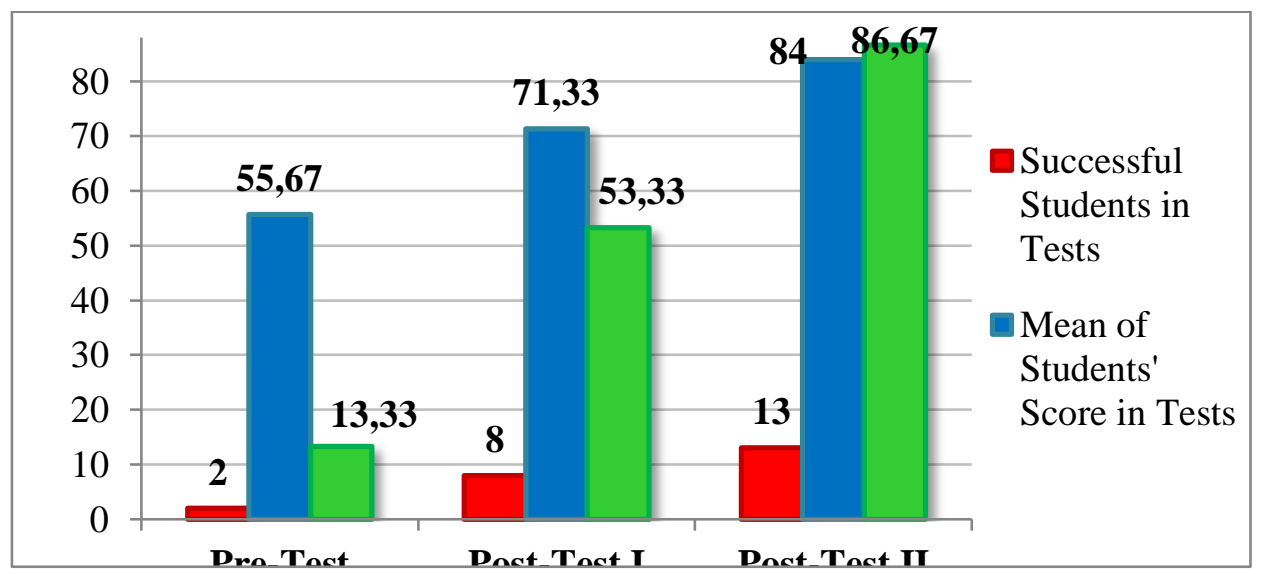

Figure 1. The improvement of results in pre-test, post-test I and post-test II after the implementation of androidbased application as media

The figure below describe the improvement of post-test I and post-test II from pretest. The results are $28.13 \%$ increasing from pre-test in post-test I and $50.89 \%$ increasing from pre-test in post-test II.

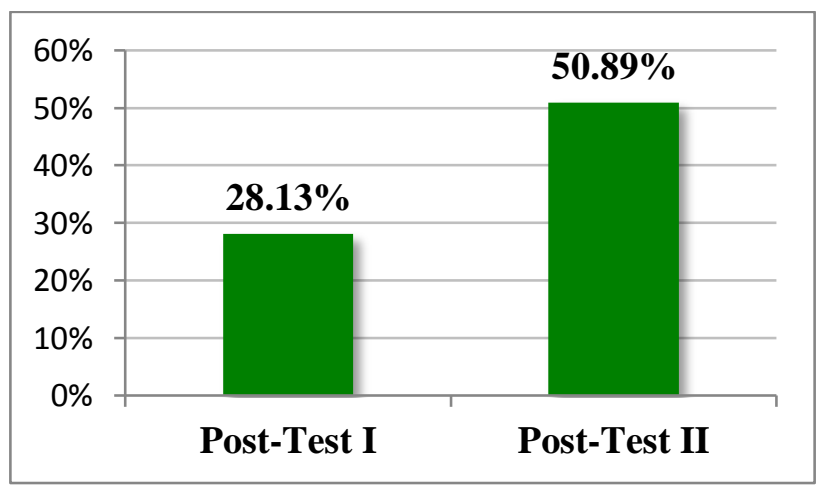


Figure 2. The improvement of post-test I and II from pre-test

Based on the result above, researcher concluded that the implementation of androidbased application as media resulted the improvement of students' understanding in simple present tense.

\section{Students Responses Toward the Implementation of Android-Based Application in the Classroom}

To analyze the responses from students toward the implementation of the media, researcher analyzed by theory of Borich. Borich in Silaban (2014) states that response of students in classroom consists of two kinds of responses they are desired and undesired responses.The result of student responses was obtained from field notes and interview result.

\section{Student Responses in Field Notes}

Researcher concluded that all of the responses of students in this study show desired and positive response. The difference of the response is only how the students express it. There are verbal and non-verbal responses. Non-verbal response is more shown in the classroom than verbal response. It can also be concluded that this media increase students' interest and motivation in learning. They are active in the classroom and no one looks bored or uninterested during the lesson.

\section{Students Responses in Students' Interview}

Researcher took seven students of 15 students to be interviewed after cycle 2 . The first question is about the difficulties that the students' get in learning grammar, especially in learning simple present tense. Five from seven students or $71.4 \%$ of the students told that they had problem in the pattern of sentence. $57.14 \%$ of them or 4 of 7 students said that they got difficulties in determining the verb (e.g V or $\mathrm{V}+\mathrm{s}$ ) and the other difficulties are the word selection and transforming the sentence.

The second question is about kinds of media used in learning grammar. $86 \%$ of student said that they learn grammar by PowerPoint presentation, $71.4 \%$ said by using worksheet and drilling. $42.8 \%$ of them said that they also learn through games. And the other answer by picture, card and film.

The third question is for getting the students opinion about learning using the media in question number two. From their opinion, 71.4\% said that the media is boring. They needed some new media in learning. $28.5 \%$ said that the media are still not effective and they felt sleepy while learning. And the other said that the media is not interesting.

The forth question is about what is their opinion about the implementation of android-based application as teaching media in their classroom. The result from the interview 
are $57.14 \%$ said that the implementation of android-based application in the classroom make the easier and more interested in learning. The other $42.8 \%$ said that it made them understand more, $28.5 \%$ said it is an exciting and good media.

The last question is whether the android-based application media helped them to get more understanding in learning simple present tense. $100 \%$ of students said that the androidbased application media helped them to get more understanding in learning simple present tense.

\section{DISCUSSIONS}

Based on the result of the data analysis and the interpretation of data in the previous chapter, the writer concludes that the implementation of android-based application as media can improve students understanding in simple present tense. From the field notes, researcher concluded that the implementation of android-based application in the classroom was successful. All of the response found during the implementation is positive and desired response. It can be seen from their feeling, behavior and their action toward the classroom activities. From the interview, researcher can conclude that this implementation can solve the problem of students in learning simple present tense. $71.4 \%$ of the students said that they used to be bored and the other $28.5 \%$ said the media before were not effective. All of the students agreed that the implementation of android-based media in the classroom help them to understand more in simple present tense. $57.14 \%$ said that the implementation of androidbased application in the classroom make the easier and more interested in learning. The other $42.8 \%$ said that it made them to understand more, $28.5 \%$ said it is an exciting and good media.

\section{REFERENCES}

Dewifartina, Ridhatul. (2011). Developing students' ability of simple present tense through subtitution drills. Jakarta: Syarif Hidayatullah State Islamic University.

Hopkins, David. (2008). A teacher's guide to classroom research (4 ${ }^{\text {th }}$ Edition). England: McGraw-Hill Open University Press.

Ovalina. (2010). Improving students' ability in using the simple past tense through contextual teaching Llarning. Jakarta: Syarif Hidayatullah State Islamic University.

Ruis, N., Muhyidin, Tri W. (2009). Instructional media. Jakarta: Ministry of National Education. 
Dewi Yana and Farahdila Fajar Darwati; The Implementation of Android-Based Application as a Media...

Silaban, Jelita. (2014). Students' responses through the application of cooperative learning type numbered head together (NHT) in Junior High School. Salatiga: Satya Wacana Christian University. 